null • Business of Knowing, summer 2021

\title{
Video and Knowledge Communication
}

\author{
Peter B. Kaufman ${ }^{1}$
}

${ }_{1}$ MIT Open Learning

Published on: Aug 16, 2021

DOI: $10.21428 / 6 \mathrm{ffd} 8432.22 \mathrm{ccbe} 45$

License: Creative Commons Attribution 4.0 International License (CC-BY 4.0). 
What if, one day, advances in human knowledge could be represented in images, recorded sound, and moving pictures - audiovisually, in a word - rather than, as they are now, predominantly in text? Could such a thing happen? The July 2021 issue of the New England Journal of Medicine, for example, has run an article (in text) about treating HIV in sub-Saharan Africa. $\underline{1}$ One day, when we develop a system of citations in video as robust as print citations have become, and a scientific community as used to watching videos as it is to reading articles, could we imagine seeing an illustrated, footnoted, recorded, easily searchable TED-type talk taking the place of this 3,800word piece in print? This type of video could, more prominently than the text does, showcase multiple dimensions of the research. There could be moving images of the patients and the laboratories; voice interviews with the doctors and the scientists; animations of the chemistry. A fully responsible video about this NEJM study also could highlight, with voice, moving images, and text, in fuller ways than the text-only article does, the fact that one of the pharmaceutical enterprises (Janssen Johnson \& Johnson) profiled in the study is actually also sponsoring the study (and the research, and the authors) - a financial relationship that should, for ethical reasons, be rendered much more transparent. The NEJM in fact has published a two-minute-and22-second animated video summary of this article, copyright @ the Massachusetts Medical Society (but without any kind of funding disclosure) at the end of the full text to online. Indeed, the Journal is producing quite a lot of multimedia content now categories include "Audio Clinical Practice," "Audio Interviews, "Audio Weekly Summaries," "Interactive Medical Cases," these "Quick Takes," "Research Summaries," and "Videos in Clinical Medicine" $\underline{2}$ — so this seemingly distant day may not be too far off.

Just because a thing doesn't exist today doesn't mean it won't exist later. Today we routinely publish our research and findings about scientific, technical, and medical progress in scholarly articles and monographs. However, we didn't do that before the development and widespread use of what they call alphabetic letterblock printing, all of which began some 500 years ago. With audio and video production and distribution technology now available on laptop computers and cell phones, and becoming as ubiquitous and as much a part of the vernacular as print, could we be sliding into a phase of human communication where this medium too, now, is catching up to the message?

What would it do to the scholarly ecosystem - and to science, medicine, the humanities, human progress - to render the great article topics of today audible and 
watchable online? It turns out that the arc of human communication has always bent, over time (over the long term, anyway, which is to say over multiple centuries), toward greater access to information, to media, and to the means of media production, rather than toward less. Adopting this kind of long-view perspective, we can see that happening even within our own learning institutions. $\underline{3}$ But could we, as the scholarly community, accelerate things a bit by producing media that many more people could listen to, watch, and use? Could we reach more audiences than just those privileged few we reach now, the ones who have access to the textual equivalents still gated and paywalled by the journal oligopolies and our university presses? $\underline{4}$

The philosopher and historian Walter Ong has said, "If knowledge is power, knowledge of how to generate knowledge is power over power." $\underline{5}$ The wheel, the sail, the compass, the clock, the lens, all the things that have facilitated knowledge and exploration, came about well before the advent of printing. Advances in scholarship, science, and civilization are not necessarily wedded to print. Ong would tell us that we are in the third phase of human communications today: the first being the unrecorded word (oral culture), which lasted for most of human existence; the second being the "denatured" word (the alphabet and print), which is only a few thousand years old; and the third being the word electrified for our new "sensorium," a process that dates back only a couple hundred years, really to the start of radio and electricity. $\underline{6}$ All these things writing, printing, the telegraph, the radio, film, television, video - seemed complicated at the time of their introduction. Indeed writing, when it first appeared, was a brand new technology, much as we regard cameras and microphones as brand new technologies today. And it was treated as such. Writing called for the use of new "tools and other equipment," "styli or brushes or pens," "carefully prepared surfaces such as paper, animal skins, strips of wood," "as well as inks or paints, and much more." In fact writing seemed so complicated and time-consuming that we used to outsource it, much like we might outsource video production now. "In the West through the Middle Ages and earlier," Ong says,

almost all those devoted to writing regularly used the services of a scribe because the physical labor writing involved - scraping and polishing the animal skin or parchment, whitening it with chalk, resharpening goose-quill pens with what we still call a pen-knife, mixing ink, and all the rest - interfered with thought and composition. $\underline{7}$

Today, fewer and fewer Americans are receiving their news and information from print. $\underline{8}$ What remains unknown is through what mode or medium - the person-to- 
person spoken word, the written word, the printed word, or the electronic word, to use Ong's categories; print or audio or video, to use mine - we are transmitting and receiving our primary knowledge today. Imagine the new news network / channel / platform that we could establish by adapting to video and sound the top articles in research journals (articles that are all still mired in text, in print editions to which our libraries all still dolefully subscribe). Science, for example, offers its readers primarily these choices: "Summary"; "Full text"; and "PDF." Imagine if instead we could watch video stories on - to pick from their current topics - "European deadly floods leave scientists stunned"; "Project launched to look for extraterrestrial visitors to our solar system"; Gamma-ray emissions from the Crab Nebula; the connections between jurisprudence and popular psychology; and the animal DNA you can find just by swabbing the air. $\underline{9}$ Or better still, to watch them freely - that is, freely licensed! - and to share them!

Though it may be slowly, the video libraries and offerings at many of these publications are growing. $\underline{10}$ That's a good thing. We've been living through years now of recorded video - of the endless lying of Donald Trump, of the insurrectionists he spun up to try to stay in power, of COVID denialism - on our screens. As the history of the $21^{\text {st }}$ century gets told, being able to access video archives of the public record and use them to produce our stories of progress, in the humanities as well as the sciences, will become a, perhaps even the, signal challenge of $21^{\text {st }}$-century publishing.

The United Nations Secretary General has dubbed our current crisis one of "Trust Deficit Disorder," and in a recent article (coulda been a video) we can read about the networking of trust, particularized trust, and the big buzzkiller - trust that exists only in "who you know." 11 The type of medium one consumes knowledge through may correspond with the type of trust that person/reader/listener/viewer develops in the message that's conveyed. Perhaps I trust something more when I hear a friend say it to me in person than if I read it in a newspaper, hear it on the radio, listen to it in a podcast, or watch the video of it on television or online. Ong might say we're going backwards.

For these reasons and for many others, the main thing is not only to publish more video, but to render the materials that we publish in video and in every medium more verifiable, perhaps though citation schemes such as we have developed with footnotes and endnotes and data repositories now over the past 400 years. Publishing more video may, in the end, make more material more accessible; may make it more trustworthy; may make access to more knowledge more democratic; and correspond to 
the trend that scholars have identified as that trend, again: the arc of information bending toward greater freedom. $\underline{12}$

Whatever articles, videos, and podcasts we publish, the main thing is to link to sources (video is woefully behind in this); to cite them well and completely; to be able to verify what we and others produce - using every tool in our belt. $\underline{13}$ Print is good, but it hasn't accomplished what it could. Elsevier publishes something called The Journal of Pain. That's a helluva title. When you get one of the articles in it - this one below, by a doctor - the links in the author bio will show you who bought the space (and, in fact, the author):

The author received no financial support related to the creation and/or production of this manuscript. The author was the inventor and developer of oral transmucosal fentanyl citrate, including Actiq and Oralet, but has no relationship with TEVA or any of the generic companies that currently market these products. The author also has no relationship to any of the companies that are developing or have developed and/or market or sell any of the other rapid-acting fentanyl products or the fentanyl patches currently being sold today except he is a director of the Board of a public company Insys Therapeutics. Insys developed and currently markets and sells Subsys, a rapid-onset sublingual fentanyl spray that is approved for breakthrough cancer pain in opioid-tolerant patients. $\underline{14}$

But only a search through press articles NOT in the article or linked to it today will tell you the deeper details about the author's involvement in fentanyl. $\underline{15}$ Only a search of his stock and stock option trades will show you details of the income he derived from his work touting opioids. $\underline{16}$ Only a search of court cases and judgments will show you a glimpse of the extensive societal damage his work actually wreaked. $\frac{17}{1}$ And only a separate search of his patents will show you how his research institution has benefited — in the millions of dollars - from the medical scourge of our time. $\underline{18}$

We should have the ability to have these links all before us, at once, and to add them to the articles and the archives, whether the medium is print, audio, or video. That way, the video conversations that are cited and imagined in this essay - the ones that are already available, and the ones that will be produced, one day down the line - will all be worth watching. 
Peter B. Kaufman works at MIT Open Learning. He is the author of The New Enlightenment and the Fight to Free Knowledge (New York: Seven Stories Press, 2021) and the forthcoming A Manual of Video Style (MIT Press), from which this essay is adapted.

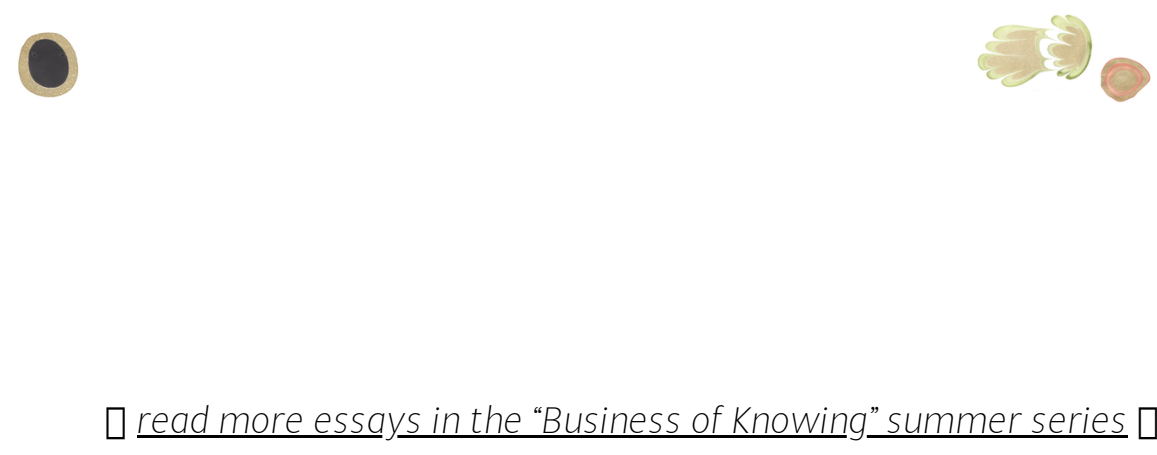

\section{Footnotes}

1.

Nicholas I. Patton, et al., "Dolutegravir or Darunavir in Combination with Zidovudine or Tenofovir to Treat HIV," New England Journal of Medicine 385, pp. 330-341, online at: https://www.nejm.org/do/10.1056/NEJMdo006101/full/ (https://doi.org/10.1056/NEJMoa2101609).

The accompanying video summary, "Second Line Treatments for HIV Infection," is part of a line of productions called "NEJM Quick Takes" embedded in the online magazine. The "Supported by Janssen" information credit appears only once in the metadata of the long-form printed article, not in the video (and not, alas, in or near the clinical trial data [https://clinicaltrials.gov/ct2/show/NCT03988452]).

Janssen produces many medications; it is also, various recent lawsuits have reminded us, the original producer of the deadly drug fentanyl (https://www.texasattorneygeneral.gov/sites/default/files/images/admin/2019/Press/20 19-0903\%20States\%20Original\%20Petition.pdf)..

2. To view all NEJM multimedia current as of this writing, see: https://www.nejm.org/multimedia?query=main_nav lg. To view all NEJM Quick Takes, see: https://www.nejm.org/multimedia/quick-take-video. 3. Stanford University historian and open-access advocate John Willinsky, studying the relationships of scholarship to rights, licenses, and publishing over millennia, has written that "historical efforts to increase and improve access - through copying and translation, paper and printing, libraries and academies - were among the more 
constant and inventive activities of learned institutions." See: John Willinsky, The Intellectual Properties of Learning: A Prehistory from Saint Jerome to John Locke (Chicago: University of Chicago Press, 2017), p. 8. $\subseteq$

4. See historian Peter Baldwin's forthcoming book, Athena Unbound:Why and How Academic Knowledge Should Be Free for All. One analysis of 45 million documents published over 40 years and indexed in the Web of Science (at https://clarivate.com/webofsciencegroup/solutions/web-of-science/, so itself now privatized [BARF]!) describes the ongoing consolidation of companies like ReedElsevier, Wiley-Blackwell, Springer, and Taylor \& Francis. Vincent Larivière, Stefanie Haustein, and Philippe Mongeon, "The Oligopoly of Academic Publishers in the Digital Era," PLOS ONE, June 15, 2015, online at https://journals.plos.org/plosone/article?id=10.1371/journal.pone.0127502 (https://doi.org/10.1371/journal.pone.0127502). See also: https://aupresses.org/membership/membership-list/.. 5. Walter J. Ong, S.J., "Knowledge in Time," in Ong, ed., Knowledge and the Future of Man: An International Symposium (New York: Holt. Rinehart \& Winston, 1968), p. 25. $\doteq$

6. Walter J. Ong, S.J., The Presence of the Word: Some Prolegomena for Cultural and Religious History (New Haven: Yale University Press, 1967). $\subseteq$

7. Walter J. Ong, S.J., "Writing is a Technology that Restructures Thought," in Gerd Baumann, ed., The Written Word: Literacy in Transition (Wolfson College Lectures 1985) (Oxford: Clarendon Press, 1986), pp. 30, 35. See also Andrew Robinson, "Writing Systems," Daven Christopher Chamberlain, "Paper," and James Mosley, "The Technologies of Print," in Michael F. Suarez, S.J. and H.R. Woodhuysen, The Oxford Companion to the Book (New York: Oxford University Press, 2010), online (behind a paywall $[B A R F !]$ ) at: https://www.oxfordreference.com/view/10.1093/acref/9780198606536.001.0001/acref $\underline{-9780198606536} . \pm$

8. https://www.pewresearch.org/topic/news-habits-media/news-media-trends/state-ofthe-news-media-project/ $\triangleq$

9. https://science.sciencemag.org/content/373/6553/372; https://www.sciencemag.org/news/2021/07/project-launched-look-extraterrestrialvisitors-our-solar-system; https://science.sciencemag.org/content/373/6553/372; 
https://science.sciencemag.org/content/373/6553/425;

https://science.sciencemag.org/content/373/6553/394;

https://www.sciencemag.org/news/2021/07/dna-pulled-thin-air-identifies-nearby= animals

10. https://www.sciencemag.org/tags/video; https://www.nature.com/nature/videos; https://www.youtube.com/user/NEJMvideo $\triangleq$

11. Terry Flew, "The Global Trust Deficit Disorder," A Communications Perspective on Trust in the Time of Global Pandemics," Journal of Communication 71, Issue 2, April 2021, pp. 163-186, online at:

https://academic.oup.com/joc/article/71/2/163/6252344

(https://doi.org/10.1093/joc/jgab006)..

12. Willinsky, The Intellectual Properties of Learning. $\_$

13. Which is the whole point of this year's book, dammit: Peter B. Kaufman, The New Enlightenment and the Fight to Free Knowledge (New York: Seven Stories Press, 2021), freely available online at: https://new-enlightenment.pubpub.org $L=$

14. Theodore H. Stanley, "The Fentanyl Story," Journal of Pain, 15 (No. 12,

December 2014), online at: https://www.jpain.org/article/S1526-5900(14)00905-5/pdf (emphasis added).

15. https://www.nytimes.com/2017/08/04/us/ted-stanley-dead-fentanyl-lollipop$\underline{\text { inventor.html }} \triangleq$

16. https://www.insider-monitor.com/trader/cik938296.html $\leftrightarrows$

17. http://www.howardsmithlaw.com/Complaints/INSYS_Complaint.pdf. See also footnote $1 . \pm$

18.

https://patentimages.storage.googleapis.com/4e/82/7a/3371be786d1008/US4671953. pdf; https://medicine.utah.edu/anesthesiology/history/stanley.php

For more on opioids, read Patrick Radden Keefe, Empire of Pain: The Secret History of the Sackler Dynasty (New York: Doubleday, 2021). Better yet, watch the movie. See Alex Gibney, "The Crime of the Century," online at: https://www.hbo.com/documentaries/the-crime-of-the-century. $\triangleq$ 